\title{
Pembuatan Salinan Akta Berdasarkan Protokol Notaris Werda Yang Telah Diserahkan Pada Notaris Pemegang Protokol
}

\author{
Lentra Nugraha \\ Fakultas HukumUniversitas Islam Indonesia Yogyakarta Indonesia \\ Jl. Cik Di Tiro No. 1, Yogyakarta, Indonesia 55223 \\ lentranugraha51@gmail.com
}

\begin{abstract}
The problems raised in this research are: First, what are the legal consequences for the switched protocol holder being able to make a copy pf deed based on the minutes that have been submitted? Second, how is the protocol for the retired notary make a copy of deed of the minute? This legal research is a combination of normative and empirical study, which uses a statutory and case-based approach and qualitative analysis methods. The results of this study conclude that the legal consequence for switching protocol holders is that they can make a copy of deed based on the minute that has been submitted. As for a damaged certificate, a copy cannot be made again, whereas if the certificate is in good condition then a copy can be made based on its contents. It is the notary who holds the minute of the deed (the recipient of the protocol from the retired notary) who can make the copy, and if the minute is damaged due to negligence then the notary must be responsible, including the one who submitted the protocol (the retired notary). Furthermore, the Notary protocol from another Notary which at the time of submission is 25 years old or more must also be submitted by the Notary who receives the protocol to the Regional Supervisory Council.
\end{abstract}

Key Words: Notary; notary protocol; retired notary

\begin{abstract}
Abstrak
Permasalahan yang diangkat dalam penelitian ini adalah: Pertama, apa konsekuensi hukum bagi pemegang protokol beralih dapat membuat akta salinan berdasarkan minuta yang telah diserahkan?Kedua, bagaimana pembuatan akta salinan terhadap protokol minuta aktanya dibuat oleh Notaris Werda? Penelitian hukum inimerupakan gabungan penelitian normatif dan empiris, yang menggunakan pendekatan pendekatan perundang-undangan dan kasus, serta dengan metode analisis kualitatif. Hasil dari penelitian ini menyimpulkan, bahwa konsekuensi hukum bagi pemegang protokol beralih yakni dapat membuat akta salinan berdasarkan minuta yang telah diserahkan. Untuk minuta akta yang rusak, maka salinan tidak dapat dibuat lagi, sedangkan jika minuta baik maka salinan dapat dibuat berdasarkan isinya. Notaris yang memegang minuta akta-lah (penerima protokol dari notaris werda) yang dapat membuat salinan tersebut, dan jika minuta rusak disebabkan oleh kelalaian maka notaris harus bertanggung jawab termasuk notaris yang menyerahkan protokol (werda). Selanjutnya, protokol Notaris dari Notaris lain yang pada waktu penyerahannya berumur 25 tahun atau lebih juga harus diserahkan oleh Notaris penerima protokol kepada Majelis Pengawas Daerah.
\end{abstract}

Kata- kata Kunci: Notaris; notaris werda; protokol notaris 


\section{Pendahuluan}

DiIndonesia dikenal adanya Notaris dan Undang-Undang yang mengatur Notaris pertama yaitu Staatsblad Nomor 3 Tahun 1860 (PJN) lebih dikenal dengan Reglement op het notaris ambt indisch, hingga tahun 2004 dibentuklah UndangUndang Nomor 30 Tahun 2004 Tentang Jabatan Notaris. Dalam perjalanannya dan perkembangannya muncul suatu masalah yang tidak sesuai dengan peraturan Undang-Undang dan prakteknya, maka penyempurnaan UndangUndang dilakukan dengan cara penambahan, penghapusan dan penggantian pasal per pasal terhadap Undang-Undang Nomor 30 Tahun 2004 tentang Jabatan Notaris.

Notaris yaitu pejabat umum yang berwenang untuk membuat akta otentik, sejauh pembuatan akta otentik tersebut tidak dikhususkan kepada Pejabat umum lainnya, hal ini diatur dalam Undang-Undang Nomor 2 Tahun 2014 tentang perubahan atas Undang-Undang Nomor 30 Tahun 2004 tentang Jabatan Notaris (selanjutnya disebut UUJN). Notaris sebagai pejabat umum adalah subyek yang menjalankan ketentuan yang diatur oleh negara, lebih khususnya dibidang hukum perdata. Dalam pembuatan akta autentik Notaris untuk menciptakan kepastian, ketertiban dan perlindungan hukum.

Selanjutnya Notaris berwenang untuk membuat akta otentik dan kewenangan lainnya yang terdapat dalam Pasal 15 UUJN, serta kewajiban Notaris dalam Pasal 16, salah satu ayat pada ayat (2) menjelaskan bahwa membuat Akta dalam bentuk Minuta Akta dan menyimpannya sebagai bagian dari Protokol Notaris, maka hal ini jelas bahwa protokol notaris tidak hanya dokumen pendukungnya saja tetapi akta otentik yang dibuat oleh atau dihadapannya. Pada Pasal 1 angka 13 UU Jabatan Notaris mendefinisikan protokol notaris sebagai kumpulan dokumen yang merupakan arsip negara yang harus disimpan dan dipelihara oleh Notaris. Hal ini jelas bahwa tidak dapat bebas menyimpan protokol Notaris.

Protokol Notaris itu sendiri merupakan dokumen negara yang harus dipelihara dan disimpan oleh Notaris, dalam Pasal 1 angka 13 UUJN Protokol Notaris merupakan dokumen negara yang dapat berfungsi sebagai bukti tertulis untuk pembuktian di pengadilan, bahwa protokol Notaris adalah kumpulan dokumen yang merupakan arsip negara yang harus disimpan dan dipelihara oleh notaris sesuai dengan ketentuan peraturan perundang-undangan dan tidak hanya dokumen pendukung saja yang merupakan protokol notaris tetapi asli akta atau minuta akta termasuk didalamnya, sesuai dengan Pasal 16 UUJN yaitu membuat 
akta dalam bentuk minuta akta dan menyimpannya sebagai bagian dari protokol notaris.

Minuta akta termasuk akta otentik, menurut Tan Thong Kie dalam bukunya, menjelaskan bahwa suatu akta menjadi otentik jika memenuhi syarat yang telah ditentukan Undang-Undang Pasal 1868 KUHPerdata dan UUJN, oleh karena itu seorang notaris dalam melaksanakan tugasnya tersebut wajib melaksanakan dengan penuh disiplin, professional dan integritas moralnya tidak boleh diragukan dan apa yang tertuang dalam awal sampai dengan akhir akta. ${ }^{1}$

Notaris bertanggung jawab terhadap aktanya hingga menjadikan protokolnya, Notaris harus bertanggung jawab atas aktanya dari awal meminta dokumen kepada klien, pembuatan aktanya hingga penandatanganan akta, hal ini disebut dengan verlijden akta atau peresmian akta, yang tertuang dalam Pasal 16 UUJN huruf $\mathrm{m}$ yaitu membacakan akta di hadapan penghadap dengan dihadiri oleh paling sedikit 2 orang saksi, atau 4 orang saksi khusus untuk pembuatan Akta wasiat di bawah tangan, dan ditandatangani pada saat itu juga oleh penghadap, saksi, dan Notaris. Setelah peresmian akta, Notaris wajib untuk menyimpan protokolnya dan mempertanggung jawabkan protokolnya sesuai yang tertuang dalam Pasal 65 UUJN Notaris.

Selanjutnya menurut Habib Adjie tentang Pasal 65 UUJN dapat dinilai tentang :

1. Mereka yang diangkat sebagai notaris, notaris pengganti, notaris pengganti khusus, dan pejabat sementara notaris dianggap sebagai menjalankan tugas pribadi dan seumur hidup sehingga tanpa ada batas waktu pertanggungjawaban.

2. Pertanggungjawaban notaris, notaris pengganti, notaris pengganti khusus, dan pejabat sementara notaris dianggap melekat, kemanapun dan dimanapun mantan notaris, mantan notaris pengganti, mantan notaris pengganti khusus, dan mantan pejabat sementara notaris berada. ${ }^{2}$

Ketentuan yang telah dijelaskan diatas tersebut bahwa notaris bertanggung jawab atas setiap akta yang dibuat atau dihadapannya meskipun protokol Notaris telah diserahkan atau dipindahkan tangankan kepada pihak penyimpan protokol notaris lain sesuai dengan ketentuan Pasal 63 ayat (4) yaitu dalam hal terjadi sebagaimana dimaksud dalam Pasal 62 huruf b, huruf c, huruf d, huruf f, atau huruf $h$, penyerahan Protokol Notaris dilakukan oleh Notaris kepada Notaris lain yang ditunjuk oleh Menteri atas usul Majelis Pengawas Daerah. Maksud dari Pasal-pasal tersebut ialah tanggung jawab protokol yang berkaitan dengan isi

1 Tan Thong Kie, Studi Notariat-Serba Serbi Praktek Notaris, Ichtiar Baru Van Hoeve, Jakarta, 2000, hlm. 166.

${ }^{2}$ Habieb Adjie, Meneropong Khasanah Notaris dan PPAT Indonesia, PT. Citra Aditya Bakti, Bandung, 2009, hlm. 43. 
akta yang telah dibuat sebagai minuta dan bukan tanggung terhadap pembuat salinan, jika Notaris pemegang protokol ialah Notaris lain dasar untuk membuat salinan yaitu minuta yang dibuat oleh Notaris sebelumnya, jadi tanggung jawab untuk membuat salinan hanya sebatas permintaan para pihak bukan tentang tanggung jawab isi akta tersebut.

Salinan itu sendiri telah diatur dalam Pasal 1 angka 9 yaitu "Salinan Akta adalah salinan kata demi kata dari seluruh Akta dan pada bagian bawah salinan Akta tercantum frasa "diberikan sebagai SALINAN yang sama bunyinya". Dalam hal ini menyebutkan yang sama bunyinya, maksudnya sama bunyinya dengan minuta akta dengan kata lain tidak ada perbedaan isi akta yang dibuat oleh atau dihadapan Notaris pembuat akta tersebut.

Hal ini menimbulkan suatu tanda tanya bahwa pemegang protokol dapat membuat salinan berdasarkan minuta yang dibuat Notaris pembuat minuta jika minuta tersebut harus mengalami pembaruan dan sampai kapan batas waktu tanggungjawab notaris terhadap akta yang dibuatnya, dibalik hal ini pada hukum keperdataan Pasal 1967 KUHPerdata menjelaskan bahwa tuntutan dalam hukum perdata akan hapus setelah melewati batas waktu 30 tahun. Sedangkan notaris adalah pejabat yang mempunyai batasan waktu pensiun di umur 65 tahun dan dapat diperpanjang 67 tahun sampai tidak menjabat menjadi notaris lagi.

Bahwa dibalik tanggung jawab terhadap protokol notaris tersebut, Notaris, Notaris Pengganti, dan Pejabat Sementara Notaris bertanggung jawab atas setiap Akta yang dibuatnya meskipun Protokol Notaris telah diserahkan atau dipindahkan kepada pihak penyimpan Protokol Notaris. Hal ini dapat dikatakan Notaris harus bertanggung jawab seumur hidup berdasarkan Pasal 65 UUJN, bagaimana dengan Notaris yang sudah pensiun (werda Notaris) apakah tanggung jawab tersebut dialihkan kepada pemegang protokol selanjutnya atau tetap melekat. Secara praktek belum tentu sama dengan teori pada UndangUndang yang berlaku dan jika terjadi masalah dikemudian hari apakah werda Notaris akan dipermasalahkan.

Masalah werda Notaris dalam permasalahannya dapat berupa permasalahan perdata maupun pidana, jika dalam akta tersebut mengandung unsur pemalsuan. Jika unsur tersebut mengandung unsur perdata pada Notaris maka tanggung jawab secara hukum yaitu ganti rugi, dan apakah sanksi perdata pada UUJN Pasal 16 ayat (12) selain dikenai sanksi sebagaimana dimaksud pada ayat (11), pelanggaran terhadap ketentuan Pasal 16 ayat (1) huruf $j$ dapat menjadi alasan bagi pihak yang menderita kerugian untuk menuntut penggantian biaya, ganti rugi, dan bunga kepada Notaris. 
Dalam pemindahan protokol ke Notaris lain secara praktek tidak mudah untuk melakukan tanggung jawabnya, jika pemegang protokol sebelumnya telah werda, dan dipidahkan ke Notaris pemegang protokol selanjutnya maka protokol Notaris tersebut telah berpindah dua kali kepada Notaris Pemegang Protokol selanjutnya, apakah hal tersebut tetap menjadi tanggung jawab Notaris pemegang protokol pertama dan apakah Notaris pemegang protokol terakhir dapat membuat salinan seperti halnya notaris pembuat minuta aktanya yang dalam contoh kasus ini ialah sejak badan hukum Perseroan Terbatas (PT) masih Naamloze Vennootschap (NV) dibuat oleh Notaris pertama sampai protokol minutanya sudah berpindah ke tiga Notaris sampai ke Notaris yang ke tiga, selanjutnya pihak pendiri PT tersebut datang untuk meminta salinan aktanya, ternyata minuta tersebut sudah rusak dan beberapa dokumen pendukungnya hilang, bagaimana salinan akta tersebut dibuat oleh Notaris pemegang protokol selanjutnya tersebut.

Hal tersebut secara yuridis tidak ada sanksi jika protokol tersebut rusak karena waktu atau karena bencana diluar kehendak manusia bukan karena kesalahan sendiri, meskipun protokol Notaris sudah di pelihara dan di simpan dengan baik sesuai peraturan UUJN. Hal ini menimbulkan masalah tentang bentuk tanggung jawab protokol notaris dan akibat hukum jika terjadi permasalahan. Atas dasar uraian tersebut penulis tertarik membahas makna dari Pembuatan Salinan Akta berdasarkan Protokol Werda Notaris yang telah diserahkan pada Notaris Pemegang Protokol

\section{Rumusan Masalah}

Berdasarkan uraian latar belakang tersebut di atas, maka permasalahan dalam penelitian ini adalah sebagai berikut: Pertama, apa konsekuensi hukum bagi pemegang protokol beralih dapat membuat akta salinan berdasarkan minuta yang telah diserahkan? Kedua, bagaimana pembuatan akta salinan terhadap protokol minuta aktanya dibuat oleh Notaris Werda?

\section{Tujuan Penelitian}

Adapun tujuan dari penelitian ini antara lain: Pertama, untuk mengetahui dan menganalisis konsekuensi hukum bagi pemegang protokol beralih dapat membuat akta salinan berdasarkan minuta yang telah diserahkan. Kedua, untuk mengetahui dan menganalisis pembuatan akta salinan terhadap protokol minuta aktanya dibuat oleh Notaris Werda. 


\section{Metode Penelitian}

Pada penelitian ini penulis menggunakan penelitian hukum normatif dan empiris artinya penggabungan penelitian normatif dan empiris. Penelitian Hukum Empiris itu sendiri yaitu penelitian hukum yang utamanya meneliti data primer, yakni data yang diperoleh langsung dari sumbernya/lapangan. Penelitian hukum normatif menurut Mukti Fajar ND dan Yulianto Ahmad adalah penelitian hukum yang meletakkan hukum sebagai sistem norma. Sistem norma yang dimaksud adalah mengenai asas-asas, norma, kaidah dari peraturan perundang-undangan, putusan pengadilan, perjanjian serta doktrin (ajaran). ${ }^{3}$

Pendekatan pada penelitian ini yaitu pendekatan yang digunakan penulis dari beberapa pendekatan diatas adalah pendekatan perundang-undangan (statute approach) dan pendekatan kasus (The Case Approach).

\section{Hasil Penelitian dan Pembahasan}

\section{Konsekuensi Hukum Pemegang Protokol Beralih dapat Membuat Akta Salinan Berdasarkan Minuta yang Telah Diserahkan}

Perjanjian Dalam praktik dunia kenotariatan tidak lepas dari kesalahan yang dialami seorang Notaris, bahwa seorang Notaris dalam menjabat mempunyai kewenangan khususnya dalam membuat akta autentik hinggal batas waktur umur 65 dan dapat diperpanjang hingga umur 67. Hal ini diatur dalam Undang undang Jabatan Notaris Pasal 8 angka (1) dan Pasal 8 angka (2), bahwa Pasal ini hanya mengatur batas waktu berakhirnya masa jabatan Notaris pada saat seorang Notaris berumur 65 tahun dan dapat diperpanjang hingga umur 67 tahun.

Di saat Notaris menjabat sebelum berakhirnya masa jabatan harus benarbenar menjaga protokol Notaris tersebut termasuk akta yang dibuatnya hingga batas waktu yang tidak diatur dalam UUJN. Notaris yang telah selesai masa jabatannya, di namakan werda Notaris, werda Notaris merupakan pensiunan sebagai seorang Notaris dan tidak mempunyai kewenangan untuk membuat akta. Protokol seorang werda Notaris harus diserahkan kepada Notaris lain yang berkedudukan sama dengannya, dalam kasus ini jika protokol seorang werda Notaris rusak maka seorang Notaris yang memegang protokol tersebut mempunyai konsekuensi terhadap minutanya, jika para pihak meminta salinan akta pada minuta werda Notaris tersebut. Protokol yang dibawa oleh Notaris pemegang protokol tidak semuanya baik dan ternyata ada yang rusak maka hal

${ }^{3}$ Mukti Fajar N.D. dan Yulianto Achmad, Dualisme Penelitian Hukum Normatif dan Hukum Empiris, Pustaka Pelajar, Yogyakarta, 2010, hlm. 34. 
ini para pihak merasa sangat butuh atas salinan tersebut dan tidak dapat dibuat oleh Notaris pemegang protokolnya. Dapat diartikan bahwa konsekuensi merupakan dampak yang terjadi jika suatu keputusan tertentu di ambil, dampak ini bisa bersifat positif atau negatif terhadap orang, benda, situasi yang berkaitan dengan keputusan tersebut. Konsekuensi hukum itu sendiri merupakan dampak terhadap perbuatan hukum yang dilakukan oleh subyek itu sendiri. Hal ini konsekuensi hukum mempunyai istilah liability yang menunjuk pada pertanggungjawaban hukum (konsekuensi hukum) yaitu tanggung jawab akibat kesalahan yang dilakukan oleh subyek hukum, sedangkan istilah responsibility menunjuk pada pertanggungjawaban politik atau kewajiban hukum. ${ }^{4}$

Dalam konsekuensi hukum terhadap Notaris dalam pembuatan salinan akta yang telah diserahkan protokolnya harus berdasarkan peraturan yang diatur oleh UUJN. Protokol notaris adalah kumpulan dokumen yang merupakan arsip Negara yang harus disimpan dan dipelihara oleh seorang Notaris. Protokol notaris terdiri dari minuta akta, daftar akta atau repertorium, buku daftar akta dibawah tangan yang penandatangannya dilakukan dihadapan Notaris atau akta dibawah tangan yang didaftar, buku daftar nama penghadap atau klapper, buku daftar protes, buku daftar wasiat, buku daftar lain yang disimpan oleh Notaris.

Notaris yang telah meninggal dunia, maka hal ini ahli waris suami/istri, keluarga sedarah dalam garis lurus keturunan semenda dua wajib memberitahukan kepada Majelis Pengawas Daerah, pemberitahuan tersebut paling lama 7 hari kerja, dan kewajiban ahli waris notaris meninggal dunia selain memberitahukan kepada Majelis Pengawas Daerah, ahli waris wajib untuk menyerahkan protokol notaris. Protokol notaris harus diserahkan paling lama 30 (tigapuluh) hari dengan pembuatan berita acara penyerahan protokol notaris yang ditandatangani oleh yang menyerahkan dan yang menerima protokol notaris. ${ }^{5}$

Hal tersebut jika Protokol Notaris tidak diserahkan oleh para ahli waris, maka Majelis Pengawas Daerah melakukan memberikan peringatan kepada ahli waris secara tertulis dan mengusulkan notaris pemegang protokol serta menyampaikan kepada Menteri. ${ }^{6}$ Kewajiban seorang notaris dalam bidang administarsi adalah menyimpan dan memelihara segala dokumen termasuk diantaranya minuta akta dan berbagai dokumen lainnya yang merupakan satu kesatuan yang disebut protokol notaris. Bahwa pada Pasal 1 ayat (13) UUJN, disebutkan Protokol Notaris adalah kumpulan dokumen yang merupakan arsip

${ }^{4}$ Ridwan H.R., Hukum Administrasi Negara, Raja Grafindo Persada, Jakarta, 2006, hlm. 335-337.

${ }^{5}$ Herlien Budiono, Dasar Teknik Pembuatan Akta Notaris, Citra Aditya Bakti, Bandung, 2013, hm. 14

'Ibid., hlm. 16 
negara yang harus disimpan dan dipelihara oleh Notaris. Pasal 1 ayat (13) UUJN tersebut tentang protokol Notaris haruslah dipelihara, disimpan dan dijaga agar tetap otentik dalam keadaan apapun meskipun notaris sedang melakukan cuti.

Protokol Notaris dapat dialihkan selain meninggal dunia, salah satunya berakhirnya masa jabatan bagi Notaris yang diatur dalam Pasal 8 ayat (1) dan Pasal 8 ayat (2) UUJN. Pasal ini mengatur berakhirnya masa jabatan Notaris pada saat Notaris berumur 65 tahun dan dapat diperpanjang hingga umur 67 tahun. Bahwa Notaris yang telah memasuki berakhirnya masa jabatan harus menyerahkan Protokol Notaris tersebut kepada Notaris lain yang telah ditunjuk oleh Majelis Pengawas Daerah (MPD), sebagaimana terdapat dalam Pasal 62 UUJN. Selain itu tanggung jawab protokol Notaris khususnya terhadap minuta aktanya hingga seumur hidup, pada Pasal 65 UUJN menyebutkan bahwa Notaris bertanggung jawab terhadap setiap akta yang dibuatnya meskipun Protokol Notaris telah diserahkan kepada pihak penyimpan Protokol Notaris. Bahwa dengan kata lain seorang Notaris tetap bertanggung jawab terhadap akta yang dibuatnya meskipun masa jabatan Notaris tersebut telah berakhir.

Pada KUHPerdata tentang tanggung jawab perdata sampai batas daluwarsa, bahwa daluwarsa (verjaring) menurut Pasal 1946 KUH Perdata adalah suatu alat untuk memperoleh sesuatu atau untuk membebaskan diri dari suatu perikatan dengan lewatnya suatu waktu tertentu dan atas syarat-syarat yang ditentukan oleh undang-undang7. Sedangkan daluwarsa dapat dibagi menjadi 2 macam, yaitu: Pertama, daluwarsa untuk memperoleh hak milik atas suatu barang (acquisitive prescription). Ketentuan dalam Pasal 1963 KUH Perdata mengatur mengenai kedaluwarsaan untuk memperoleh hak milik atas suatu barang dapat dilakukan jika terpenuhi beberapa unsur-unsur sebagai berikut, yaitu mempunyai itikad baik (Pasal 1965 dan Pasal 1966 KUH Perdata), terdapat alas hak yang sah, dan menguasai barang tersebut terus menerus selama 20 tahun atau 30 tahun tanpa ada yang menggugat. Kedua, daluwarsa untuk dibebaskan dari suatu perikatan atau dibebaskan dari tuntutan (extinctive prescription). Dalam Pasal 1967 KUHPerdata bahwa semua tuntuan hukum, baik yang bersifat kebendaan maupun yang bersifat perorangan, hapus karena lewat waktu dengan lewatnya waktu 30 tahun, sedangkan orang yang menunjuk adanya lewat waktu itu, tidak usah menunjukkan suatu alas hak, dan terhadapnya tak dapat diajukan suatu tangkisan yang didasarkan pada itikad buruk.

\footnotetext{
${ }^{7}$ Berdasarkan Pasal 1965 - 1967 KUHPerdata.
} 
Protokol yang sudah diserahkan pada notaris lain dan notaris lain menyerahkan lagi terdapat konsekuensi hukumnya, meskipun Notaris sudah tidak menjabat ataupun tidak dapat membuat akta lagi, dalam akta otentik terdapat nama Notaris pembuat akta tersebut, bahwa nama tersebut telah melekat dengan tanggung jawabnya, sehingga Notaris yang telah memasuki masa pensiun tidak lagi bertanggung jawab terhadap segala hal yang berkaitan dengan proses pembuatan akta, karena ketika notaris telah mengakhiri masa jabatannya, segala kewenangan dan tanggungjawabnya terkait dengan pembuatan akta tidak lagi dapat dilakukan dan berpindah ke Notaris pemegang protokol selanjutnya.

Namun berdasarkan ketentuan Pasal 65 UUJN, Notaris yang memasuki masa pensiun tetap bertanggungjawab terhadap akta-akta yang telah dibuatnya pada saat Notaris yang bersangkutan masih menjabat, namun dengan berakhirnya masa jabatannya sebagai Notaris maka pertanggungjawaban untuk menyimpan akta-akta atau protokol yang dimilikinya dalam bentuk fisik juga telah berakhir. Hal ini jelas bahwa Notaris yang telah berakhir masa jabatannya atau werda Notaris mempunyai konsekuensi hukum atas pembuatan aktanya termasuk kesalahan akta yang pernah werda Notaris tersebut buat.

Jika ada Perseroan Terbatas yang pada masanya dengan nama Naamloze Vennootschap $(\mathrm{NV})$ dibuat oleh Notaris pertama sampai protokol minutanya berpindah ke tiga Notaris pemegang protokol dan sampai ke Notaris yang ke tiga, selanjutnya pihak pendiri Perseroan Terbatas tersebut datang untuk meminta salinan aktanya, ternyata minuta tersebut sudah rusak dan beberapa dokumen pendukungnya hilang. Pihak pendiri Perseroan Terbatas tersebut ingin beberapa aset atas nama Perseroan Terbatas untuk dijual.

Menurut pendapat Werda Notaris Bardo Jumeno ${ }^{8}$ dalam konsekuensi hukum pemegang protokol yang beralih dapat membuat salinan akta, berdasarkan Pasal 64 ayat (1) UUJN, Majelis Pengawas Daerah menunjuk notaris yang menerima protokol notaris. Notaris yang penerima protokol berwenang untuk mengeluarkan grosse akta, salinan akta, atau kutipan akta sesuai dengan Pasal 64 ayat (2) UUJN. Hal ini berdasarkan minuta akta yang dibawa oleh penerima protokol.

Bardo Jumeno menjelaskan lebih lanjut, bahwa dalam penyerahan protokol Notaris tidak ada masalah karena sudah sesuai prosedur penyerahan protokol menurut undang-undang dengan berita acara penyerahan. Hal ini bahwa protokol yang telah diserahkan ada yang rusak dimakan oleh waktu, banjir, kebakaran atau keadaan di luar kemampuan manusia, maka Notaris yang menyerahkan protokol tersebut harus bertanggung jawab untuk melaporkan

\footnotetext{
${ }^{8}$ Hasil Wawancara dengan Werda Notaris Bardo Jumeno, pada hari Kamis 20 Februari 2020.
} 
kepada MPD, kecuali rusak karena kelalaian maka harus bertanggung jawab sesuai kerugian meskipun Notaris tersebut sudah werda. Hal ini berdasarkan Pasal 65 UUJN yaitu Notaris, Notaris Pengganti, dan Pejabat Sementara Notaris bertanggung jawab atas setiap Akta yang dibuatnya meskipun Protokol Notaris telah diserahkan atau dipindahkan kepada pihak penyimpan Protokol Notaris.

Seperti yang telah dijelaskan sebelumnya, bahwa para pihak yang meminta salinan akta pada minuta yang rusak dan telah lebih dari 30 tahun tidak dapat diberikan, dan bagaimana aset PT tersebut untuk pengurusan. Aset PT yang telah lama dan PT tidak ada penyesuaian maka harus dengan putusan pengadilan. Sesuai UUPT mengenai Penyesuaian Anggaran Dasar. Menurut pendapat reponden Notaris penerima protokol Dewi Ciptaning Pramukti 9 , konsekuensi jika protokol Notaris yang diserahkan rusak maka pembuatan salinan akta tidak bisa dilaksanakan. Dalam pembuatan salinan akta dilakukan berdasarkan minuta aktanya sesuai keterangan diakhir kalimat pada akta "....salinan ini diberikan sesuai dengan minuta aktanya..." jika tidak ada minuta maka salinan tidak akan ada.

Protokol yang diberikan oleh Notaris pemberi protokol jika sudah rusak dimakan oleh waktu/gempa bumi/banjir (force majeur) maka secara praktek tidak dapat dibuat, jika hal ini terjadi Notaris penerima protokol menyarankan untuk memberitau kepada Werda Notaris dan membuat berita acara yang dilaporkan kepada MPD atau MPW setempat. Pengaturan tentang protokol Notaris didalam UUJN tidak dijelaskan mengenai kerusakan yang diakibatkan force majeur. Jika hal ini ada permasalahan hukum tentang kelalaian terhadap minuta aktanya termasuk rusak atau hilang karena lalai, berdasarkan Pasal 16 angka 11 UUJN.

Menurut pendapat narasumber Habib Adjie ${ }^{10}$ akta notaris merupakan, asli akta atau minuta akta yang berbentuk otentik, bahwa akta otentik ini dibuat oleh atau dihadapan notaris itu sendiri. Akta otentik harus disimpan dan dipelihara dengan baik karena akta otentik yang berupa minuta akta merupakan dokemen negara yang diamanahkan notaris untuk disimpan. Konsekuensi hukum pada minuta akta tidak lepas pada tanggung jawab jabatan notaris, bahwa protokol termasuk minuta akta harus dipelihara dan dijaga seumur hidup. Hal ini diatur pada Pasal 65 UUJN dengan kesimpulan bahwa pertanggungjawaban notaris, notaris pengganti, dan pejabat sementara notaris dianggap melekat, kemanapun dan dimanapun mantan notaris, mantan notaris pengganti, mantan notaris pengganti khusus, dan mantan pejabat sementara notaris berada.

\footnotetext{
${ }^{9}$ Hasil Wawancara dengan Notaris Dewi Ciptaning Pramukti, pada Sabtu 22 Februari 2020.

${ }^{10}$ Hasil Wawancara dengan Notaris Habib Adjie melalui ponsel, pada Selasa 25 Februari 2020.
} 
Minuta akta yang telah diserahkan tidak sepenuhnya masih baik atau tidak rusak. Minuta akta notaris disimpan selama bertahun-tahun, tidak dipungkiri bahwa hal ini dapat rusak dikarenakan oleh waktu. Maka notaris penerima protokol notaris yang werda tetap menerima nya, jika ada para pihak meminta salinan pada protokol notaris terdahulu maka notaris yang menerima protokol minuta saat ini dapat memberikan penjelasan. Misal pada minuta akta yang rusak sebaiknya diberikan penjelasan bahwa minuta nya diterima dalam keadaan rusak oleh sebab rapuh karena waktu maka salinan tidak dapat dibuat lagi, dan notaris penerima protokol menyarankan untuk membuatkan lagi. ${ }^{11}$

Tentang Perseroan Terbatas yang ingin menjual asetnya tapi tidak ada salinan akta pendiriannya, para pihak yang meminta salinan akta yang minuta aktanya rusak karena waktu tidak dapat diberikan, dan aset PT tersebut tidak dapat dilakukan penjualan tanpa putusan pengadilan, kesalahan PT tidak dilakukannya penyesuaian pada UUPT terbaru. Dalam aset perseroan terbatas yang sudah tidak ada lagi akta pendiriannya dan pemilik obyek tanah tersebut masih atas nama PT, seorang ahli waris pendiri PT sebelum dilakukan peralihan hak atas tanah tersebut harus menyelesaikan dokumen tentang bukti kepemilikan tanah tersebut. Penyelesaian dokumen mengenai bukti kepemilikan tanah atas nama PT tersebut dengan cara permohonan ke pengadilan dan permohonan perpanjangan HGB pada kantor pertanahan.

Dari kesimpulan tersebut di atas bahwa Notaris yang telah meninggal atau berakhir masa jabatannya harus menyerahkan protokol notarisnya kepada penerima Protokol Notaris yang ditunjuk oleh Menteri atas usul Majelis Pengawas Daerah. Sedangkan pada Pasal 63 UUJN ayat (5) bahwa protokol Notaris dari Notaris lain yang pada waktu penyerahannya berumur 25 tahun atau lebih diserahkan oleh Notaris penerima Protokol Notaris kepada Majelis Pengawas Daerah. Melihat dari Pasal 65 UUJN yaitu Notaris, Notaris Pengganti, Notaris Pengganti Khusus, dan Pejabat Sementara Notaris bertanggung jawab atas setiap akta yang dibuatnya meskipun protokol Notaris telah diserahkan atau dipindahkan kepada pihak penyimpan protokol Notaris.

Hal ini menjadikan tanggung jawab seumur hidup pada protokol Notaris padahal umur protokol yang telah berusia 25 tahun atau lebih harus diserahkan kepada MPD. Protokol notaris yang termasuk minuta aktanya merupakan dokumen negara yang harus disimpan dan dipelihara dengan baik oleh Notaris hal tersebut diatur pada Pasal 1 angka 13 UUJN yaitu protokol notaris adalah arsip dan dokumen negara yang harus disimpan dan dipelihara oleh notaris. Konsekuensi hukum pada pemegang protokol untuk membuat akta salinan kalau 
dilihat dari Pasal 65 UUJN yaitu seumur hidup tetapi pada Pasal 63 ayat (5) yang telah berusia 25 tahun atau lebih sudah diserahkan pada MPD dan seharusnya dasar untuk membuat salinan tidak bisa dilakukan karena minuta aktanya sudah beralih kepada MPD.

Mengenai minuta akta yang sudah rusak maka salinan tidak dapat dibuat lagi, dan jika minuta baik maka salinan dapat dibuat berdasarkan isinya, bahwa siapapun notaris yang memegang minuta akta (penerima protokol dari notaris yang berakhir jabatannya atau meninggal) dapat membuat salinan tersebut. Jika minuta rusak disebabkan oleh kelalaian maka notaris harus bertanggung jawab termasuk notaris yang menyerahkan protokol (werda), tanggung jawab tersebut dapat berupa ganti kerugian jika para pihak menuntut. Selanjutnya pada Pasal 16 ayat 1 huruf $\mathrm{b}$ tentang kewajiban notaris bahwa notaris membuat akta dalam bentuk minuta akta dan menyimpannya sebagai bagian dari Protokol Notaris dan pada Pasal 16 ayat (11) Notaris yang melanggar ketentuan sebagaimana dimaksud pada ayat (1) huruf a sampai dengan huruf 1 dapat dikenai sanksi berupa: a. peringatan tertulis; b. pemberhentian sementara; $c$. pemberhentian dengan hormat; atau d. pemberhentian dengan tidak hormat.

Hal ini jelas bahwa notaris yang tidak menyimpan minuta aktanya dengan baik dapat dikenakan sanksi peringatan tertulis hingga pemberhentian tidak hormat. Jika protokol yang telah berusia 25 tahun atau lebih harus diserahkan kepada MPD secara yuridis minuta yang merupakan bagian dari protokol Notaris tersebut tidak di simpan Notaris pemegang Protokol terakhir. Hal ini seharusnya salinan tidak dapat dibuat, tetapi secara praktik minuta tersebut dapat dibuat jika minuta akta masih disimpan pada Notaris pemegang protokol terakhir.

\section{Pembuatan Akta Salinan terhadap Protokol Minuta yang Aktanya Dibuat oleh Notaris Werda}

Werda Notaris yaitu notaris yang telah pensiun atau telah memasuki usia 65 tahun dan dapat diperpanjang hingga 67 tahun. Berdasarkan Anggaran Dasar dan Anggaratan Rumah Tangga (AD ART) hasil rapat pleno pengurus pusat yang diperluas (Pra Kongres), menurut Pasal 2 menjelaskan bahwa di dalam organisasi Ikatan Notaris Indonesia, keanggotaan terdiri dari tiga macam, yaitu: a) Anggota biasa adalah setiap orang yang menjalankan tugas jabatan notaris (notaris aktif) yang terdaftar sebagai anggota perkumpulan dan mempunyai hak suara dan setiap notaris yang telah berhenti melaksanakan tugas jabatan notaris (werda notaris) karena diberhentikan dengan hormat karena telah mencapai umur yang telah ditetapkan dalam undang-undang atau berhenti atas permintaanya sendiri; 
b) Anggota luar biasa adalah setiap orang yang telah lulus program studi strata dua kenotariatan atau program pendidikan spesialis kenotariatan yang terdaftar sebagai anggota perkumpulan; c) Anggota kehormatan adalah seseorang yang mempunyai jasa sangat besar terhadap perkumpulan maupun lembaga kenotariatan.

Dari pengertian di atas, werda notaris masih mempunyai peranan dalam organisasi Ikatan Notaris Indonesia. Dalam AD/ART INI, Pasal 6 ayat (2) dan Pasal 6 ayat (5) yang menegaskan bahwa anggota biasa dari werda notaris berhak untuk mengikuti semua kegiatan perkumpulan, mengeluarkan pendapat dalam kongres, konfrensi wilayah dan konfrensi daerah, dan dipilih sebagai Anggota Dewan Kehormatan. Selanjutnya, pada Pasal 6 ayat (5) bahwa setiap anggota juga berhak untuk mendapatkan perlindungan dari Perkumpulan.

Hal ini dapat dan patut diberikan berdasarkan ketentuan dalam AD/ART Perkumpulan serta peraturan perundang-undangan yang berlaku serta mendapatkan bantuan dan layanan dari perkumpulan guna memperoleh bahan atau dokumen mengenai peraturan perundangundangan dan peraturan perkumpulan serta bahan atau dokumen lainnya yang mempunyai hubungan langsung maupun tidak langsung dengan jabatan notaris, satu dan lain dengan memperhatikan tata cara yang berlaku dalam perkumpulan.

Werda notaris mempunyai kewajiban sebagai anggota INI, yaitu sebagaimana diatur dalam Pasal 7 AD/ART INI, tetapi mengenai yang berkenaan dengan werda notaris diatur dalam Pasal 7 ayat (2) dan Pasal 7 ayat (10). Pasal 7 ayat (2) menjelaskan bahwa setiap anggota biasa dan anggota luar biasa wajib berpartisipasi aktif dalam perkumpulan. Pasal 7 ayat (10) menegaskan bahwa setiap anggota kecuali werda notaris dan anggota kehormatan, wajib membayar uang iuran bulanan serta sumbangan lain yang ditetapkan oleh perkumpulan. Apabila kewajiban tersebut tidak dipenuhi maka anggota dimaksud tidak dapat menuntut hak-hak nya.

Peranan werda notaris hanya sebatas peraturan di AD/ART INI, tetapi dalam peraturan UUJN, werda notaris mempunyai tanggung jawab terhadap protokol dan minuta aktanya seumur hidup sesuai Pasal 65 UUJN. Dalam kasus sebuah badan hukum Perseroan Terbatas (PT) yang dahulu masih berbentuk Naamloze Vennootschap (NV) yang dibuat oleh Notaris pertama sampai protokol minutanya sudah berpindah ke tiga Notaris sampai ke Notaris terakhir, apakah hal tersebut dapat dibuat salinan pada notaris yang memegang protokol sekarang.

Notaris mempunyai kewenangan membuat minuta akta berdasarkan UUJN dan KUHPerdata, Kewenangan notaris yang diberikan oleh UUJN dan 
KUHPerdata selain pembuatan minuta, notaris dapat membuat salinan yang berdasarkan minuta akta tersebut. Notaris dalam kewenangannya harus berkaitan dengan kebenaran materiil dan formil atas akta otentiknya, jika dilakukan tanpa prinsip kehati-hatian sehingga membahayakan masyarakat yang menimbulkan kerugian maka notaris harus mempertanggung jawabkan perbuatan tersebut secara perdata maupun pidana.

Dalam pembuatan salinan akta, notaris harus berdasarkan minuta yang di bawanya, jika salinan tidak dapat dibuat maka ada masalah terhadap minuta dan protokol notarisnya. Secara perdata pada Pasal 1967 KUHPerdata bahwa semua tuntuan hukum, baik yang bersifat kebendaan maupun yang bersifat perorangan, hapus karena lewat waktu dengan lewatnya waktu 30 tahun, sedangkan orang yang menunjuk adanya lewat waktu itu, tidak usah menunjukkan suatu alas hak, dan terhadapnya tak dapat diajukan suatu tangkisan yang didasarkan pada itikad buruk. Akta yang lebih dari 30 tahun tidak mempunyai alas hak untuk dijadikan dasar suatu tangkisan sebagai bukti.Werda notaris tersebut telah menyerahkan protokol hingga tiga turunan sampai lebih dari 30 tahun, hal ini menjadi daluwarsa, mengenai daluwarsa tidak dapat berjalan jika memenuhi pasal-pasal berikut :

a. Terhadap piutang yang bersyarat, selama syarat ini tidak dipenuhi (Pasal 1990 ayat (1) KUHPerdata);

b. Dalam hal suatu perkara untuk menanggung suatu penjualan, selama belum ada putusan untuk menyerahkan barang yang bersangkutan kepada orang lain (Pasal 1990 ayat (2) KUHPerdata);

c. Terhadap suatu piutang yang baru dapat ditagih pada hari yang telah ditentukan, selama hari itu belum tiba (Pasal 1990 ayat (3) KUHPerdata);

d. Terhadap seorang ahli waris yang telah menerima suatu warisan dengan hak istimewa untuk membuat pendaftaran harta peninggalan, tidak dapat dikenakan daluwarsa mengenai piutang-piutangnya terhadap harta peninggalan (Pasal 1991 ayat (1) KUH Perdata).

Dalam kasus yang terjadi pada protokol minuta akta werda Notaris yang telah di alihkan pada Notaris pemegang protokol tidak semuanya baik, ada yang rusak lebih dari 30 tahun, yaitu salinan mengenai Perseroan Terbatas, bahwa para pihak yang meminta salinan akta pada minuta yang rusak dan telah lebih dari 30 tahun tidak dapat diberikan atau tidak dapat dibuatkan, hal ini berdasarkan minuta yang dipegang oleh pemegang protokol Notaris dan untuk pengurusan aset tetap dikembalikan pada Pengadilan untuk memintakan putusan pengadila atas dasar aset PT tersebut. 
Menurut pendapat responden Werda Notaris Bardo Jumeno ${ }^{12}$ mengenai akta notaris pembuatan akta tersebut secara keperdataan, bahwa daluwarsa menurut Pasal 1967 KUHPerdata yaitu selama 30 tahun dengan syarat-syarat tertentu bukan merupakan syarat umum seperti utang piutang yang belum selesai masa berlakunya. Pada kasus tersebut diatas, yaitu merupakan protokol atau minuta akta notaris yang telah berpindah hingga tiga turunan, apakah dapat dibuat salinannya.

Salinan akta adalah ikutan dari minuta akta, jika tidak ada minuta akta maka tidak ada salinan, jika protokol atau minuta akta tersebut masih berlaku hingga lebih dari 30 tahun, maka dapat dibuat salinan aktanya dengan syarat minuta akta tersebut tidak rusak, atau masih dapat dibaca. Akta yang responden berikan kepada pemegang protokol selanjutnya tidak ada yang rusak secara kelalaian, hanya kerusakan rapuh karena waktu saja dan kebanyakan akta yang telah rapuh sudah habis masa berlakunya sehingga dalam isi akta tersebut sudah selesai/ tidak lagi ada kekuatan hukumnya.

Menurut pendapat reponden Notaris penerima protokol Dewi Ciptaning Pramukti ${ }^{13}$, tentang penerimaan protokol yang lebih dari 30 tahun lamanya, tetap diterima sesuai dengan aturan di UUJN, dan dalam pembuatan salinan akta, jika adanya minuta akta maka salinan dapat dibuat, tetapi secara yuridis responden memberikan masukan kepada para pihak, jika akta tersebut sudah sangat lama jangka waktunya dan mungkin sudah daluwarsa, jika memungkinkan untuk dibuat salinan dengan permintaan para pihak, maka tetap dibuatkan.

Dasar dari salinan akta sama seperti yang dijelaskan oleh responden Bardo Jumeno, bahwa salinan akta dibuat atas dasar minuta akta, meskipun minuta akta sudah turun menurun pemegang protokolnya. Pemegang protokol notaris harus tetap bertanggung jawab, bahwa dalam penunjukan Notaris sebagai pemegang dan penyimpan Protokol Notaris wajib untuk menerima pelimpahan protokol tersebut karena pada awal sebelum menjalankan jabatannya, setiap Notaris diharuskan membuat surat pernyataan tentang kesediaannya menampung protokol Notaris yang pindah, berhenti atau meninggal dunia. Majelis Pengawas Daerah (MPD) yang dalam tugasnya juga melakukan penunjukan penyerahan protokol Notaris bagi Notaris yang telah berakhir masa jabatannya. ${ }^{14}$

Menurut pendapat narasumber Habib Adjie ${ }^{15}$ terkait pembuatan salinan yang minuta aktanya dibuat oleh werda notaris sejak 30 tahun yang lalu, jika salinan dibuat maka ada minuta akta, minuta akta merupakan asli akta yang

\footnotetext{
12 Hasil Wawancara dengan Werda Notaris Bardo Jumeno, pada Kamis 20 Februari 2020

${ }^{13}$ Hasil Wawancara dengan Notaris Dewi Ciptaning Pramukti, pada Sabtu 22 Februari 2020.

${ }^{14}$ Ibid.

${ }^{15}$ Hasil Wawancara dengan Notaris Habib Adjie melalui ponsel, pada Selasa 25 Februari 2020.
} 
termasuk dokumen negara didalam suatu protokol notaris. Minuta akta yang telah lama disimpan kemungkinan terdapat kerusakan dan tidak dapat dibaca maka salinan tidak dapat dibuat. Sedangkan pada Pasal 70 huruf e UUJN bahwa Majelis Pengawas Daerah (MPD) berwenang menentukan tempat penyimpanan Protokol Notaris yang pada saat serah terima Protokol Notaris telah berumur 25 (dua puluh lima) tahun atau lebih.

Pasal 70 huruf e UUJN dapat dijelaskan bahwa hal tersebut menimbulkan masalah hukum yang lain, karena MPD yang akan menentukan tempat penyimpananya untuk protokol notaris yang sudah berumur 25 tahun, karena secara yuridis MPD berhak menentukan akan disimpan di tempat lain, maka siapa yang akan memberikan salinannya jika ada yang meminta. Hal ini perlu diperhatikan dalam penyimpanan minuta aktanya agar dapat dibuat salinan dengan baik.

Dalam daluwarsa menurut Pasal 1967 KUHPerdata bahwa semua tuntutan hukum, baik yang bersifat kebendaan maupun yang bersifat perorangan, hapus karena lewat waktu dengan lewatnya waktu 30 tahun, sedangkan orang yang menunjuk adanya lewat waktu itu, tidak usah menunjukkan suatu alas hak, dan terhadapnya tak dapat diajukan suatu tangkisan yang didasarkan pada itikad buruk. Tuntutan hukum secara perdata yang telah lewat 30 tahun menjadikan daluwarsa, tetapi dengan syarat-syarat tertentu, jika minuta tersebut jangka waktunya telah habis maka sebelum 30 tahun sudah tidak dapat dipakai lagi, atau tidak ada kekuatan hukum yang mengikat.

Menurut narasumber Kantor Wilayah Kementerian Hukum dan HAM Yogyakarta yaitu Hariyanto' ${ }^{16}$, mengenai minuta akta atau protokol notaris, jika notaris ingin membuat salinan, maka dasar dari salinan tersebut ialah minuta akta yang menjadi satu kesatuan dengan protokol notaris. Sedangkan tanggung jawab seorang Notaris secara administrasi adalah menerima, menyimpan, serta memegang bentuk fisik dari setiap akta yang merupakan Protokol Notaris yang harus dijaga dan dipelihara. Protokol Notaris tersebut berakhir bersamaan dengan dengan berakhirnya seorang Notaris (notaris yang menigggal). Tanggung jawab seorang Notaris terhadap penyimpanan akta dapat berakhir namun pertanggungjawaban atas adanya kesalahan dalam pembuatan akta tidak akan pernah berakhir meskipun Notaris yang bersangkutan telah berakhir masa jabatannya (Pasal 65 UUJN).

${ }^{16}$ Hasil Wawancara dengan pihak Kemenkum HAM Hariyanto, pada Senin 24 Februari 2020. 
Dalam kasus tersebut suatu akta perseroan yang sudah habis masa berlaku secara perdata (30 tahun) dan jika minuta akta yang telah diserahkan kepada notaris pemegang protokol hingga tiga kali turunan sampai minuta aktanya rusak, maka tidak dapat dibuat salinan. Seharusnya tanggung jawab protokol notaris hanya sebatas 25 tahun karena pada Pasal 63 ayat (5) UUJN menyebutkan bahwa Protokol Notaris dari Notaris lain yang pada waktu penyerahannya berumur 25 (dua puluh lima) tahun atau lebih diserahkan oleh Notaris penerima protokol Notaris kepada Majelis Pengawas Daerah. Sedangkan pada Pasal 70 UUJN, mengenai kewenangan Majelis Pengawas Daerah, menyebutkan salah satu kewenangan Majelis Pengawas Daerah adalah menentukan tempat penyimpanan Protokol Notaris yang pada saat serah terima protokol Notaris telah berumur 25 (dua puluh lima) tahun atau lebih.

Notaris penerima protokol yang lebih dari 30 tahun seharusnya memberitahu kepada MPD sesuai dengan Pasal 63 ayat (5) tersebut, apakah salinan akta masih bisa dibuat setelah lewat 25 tahun yang seharusnya diserahkan kepada MPD, dari analisis penelitian yang dilakukan penulis menurut responden dan narsumber, jika para pihak meminta salinan akta pada notaris penerima protokol yang lebih dari 30 tahun dapat dibuat jika ada minuta akta yang masih berlaku dan dapat dibaca dengan baik, dan jika rusak maka tidak dapat dibuat.

\section{Penutup}

Dari uraian di atas, maka dapat disimpulkan bahwa: (1) Konsekuensi hukum pemegang protokol beralih dapat membuat akta salinan berdasarkan minuta yang telah diserahkan, bahwa protokol notaris termasuk minuta aktanya merupakan dokumen negara yang harus disimpan dan dipelihara dengan baik oleh Notaris hal tersebut diatur pada Pasal 1 angka 13 UUJN yaitu protokol notaris adalah arsip dan dokumen negara yang harus disimpan dan dipelihara oleh notaris. Minuta akta yang rusak pada kasus ini maka salinan tidak dapat dibuat lagi termasuk salinan dalam akta pendirian PT, dan jika minuta baik maka salinan dapat dibuat berdasarkan isinya, bahwa siapapun notaris yang merupakan penerima protokol dari notaris yang berakhir jabatannya atau meninggal dapat membuat salinan tersebut. Jika minuta rusak disebabkan oleh kelalaian maka notaris harus bertanggung jawab termasuk notaris yang menyerahkan protokol (werda), hal ini berdasarkan Pasal 65 menyebutkan bahwa Notaris bertanggung jawab terhadap setiap akta yang dibuatnya meskipun Protokol Notaris telah diserahkan kepada pihak penyimpan Protokol Notaris,sedangkan; (2) pembuatan akta salinan terhadap protokol minuta aktanya dibuat oleh Werda Notaris, werda notaris disini telah turun menurun hingga 3 
kali, sehingga ada protokol notaris yang lebih dari 30 tahun. Dapat dilihat dari Pasal 63 ayat (5) UUJN menyebutkan bahwa Protokol Notaris dari Notaris lain yang pada waktu penyerahannya berumur 25 tahun atau lebih diserahkan oleh Notaris penerima protokol Notaris kepada Majelis Pengawas Daerah. Notaris penerima protokol yang lebih dari 30 tahun seharusnya memberitahu kepada MPD, jika para pihak meminta salinan akta pada notaris penerima protokol yang lebih dari 30 tahun dapat dibuat tetapi ada minuta akta yang masih berlaku dan dapat dibaca dengan baik, dan jika rusak maka tidak dapat dibuat.

Adapun yang dapat penulis sarankan melalui penelitian ini: (1) Untuk pemerintah agar dikaji lebih dalam Undang-Undang yang berkaitan dengan Notaris, khususnya Undang-Undang Jabtan Notaris dan peraturan pelaksananya; (2)Notaris harus selalu berhati-hati dalam menjalankan jabatannya, terutama dalam pembuatan salinan akta agar teliti. Notaris yang teliti akan berjalan dengan baik dalam jabatannya, dan; (3) Organisasi Ikatan Notaris Indonesia (INI) harus tetap memberikan koordinasi terhadap Notaris. Hal ini untuk menjaga anggotanya agar tetap profesional dalam menjalankan jabatannya.

\section{Daftar Pustaka}

\section{Buku}

Adjie, Habib, Meneropong Khasanah Notaris dan PPAT Indonesia, PT. Citra Aditya Bakti, Bandung, 2009.

Budiono, Herlien, Dasar Teknik Pembuatan Akta Notaris, Citra Aditya Bakti, Bandung, 2013.

H.R., Ridwan, Hukum Administrasi Negara, Raja Grafindo Persada, Jakarta, 2006.

Kie, Tan Thong, Studi Notariat-Serba Serbi Praktek Notaris, Ichtiar Baru Van Hoeve, Jakarta, 2000.

N.D., Mukti Fajar dan Yulianto Achmad, Dualisme Penelitian Hukum Normatif dan Hukum Empiris, Pustaka Pelajar, Yogyakarta, 2010.

\section{Peraturan Perundang-Undangan:}

Kitab Undang-Undang Hukum Perdata.

Undang-Undang Nomor 2 Tahun 2014 Tentang Perubahan Atas Undang-Undang Nomor 30 Tahun 2004 Tentang Jabatan Notaris. 